Insecticidal Efficacy of Native Diatomaceous Earth against Potato Tuber Moth, [Phthorimaea operculella (Zeller) (Lepidoptera: Gelechiidae)], Pupae

\author{
Turgut ATAY ${ }^{\circ}$, Mustafa ALKAN 2 , Sait ERTÜRK ${ }^{3}$ \\ ${ }^{1}$ Department of Plant Protection, Faculty of Agriculture, Tokat Gaziosmanpasa University, Tokat, Turkey \\ ${ }^{2,3}$ Plant Protection Central Research Institute, Ankara, Turkey \\ ${ }^{1}$ https://orcid.org/0000-0002-9074-0816, ${ }^{2}$ https://orcid.org/ 0000-0001-7125-2270, ${ }^{3}$ https://orcid.org/ 0000-0001-9961-3955 \\ $\square$ : turgut.atay@gop.edu.tr
}

\begin{abstract}
In this study, the insecticidal activity of native diatomaceous earth (DE) Turco004 was tested against pupae of the Potato tuber moth, [Phthorimaea operculella (Zeller) (Lepidoptera: Gelechiidae)] in laboratory conditions. In the bioassays were used dust formulation and applied four concentrations $\left(2.5,5,10\right.$ and $\left.20 \mathrm{~g}^{-\mathrm{m}^{2}}\right)$ of DE. Pupa weights and the number of adults emerging from the pupae were recorded after $24,48,72,96,120,144$ and 168 hours of diatomaceous earth exposure. It was concluded that the weights of the pupae are significantly affected depending on exposure time. In addition, pupal eclosion was prevented, and no adult emergency was observed at all concentration applied. The data obtained revealed that the native diatom soil Turco004 may have a potential in the control of $P$. operculella at all applied doses.
\end{abstract}

\section{Yerli Diyatom Toprağının Patates Güvesi [Phthorimaea operculella (Zeller) (Lepidoptera: Gelechiidae) Pupasına Karşı Böcek Öldürücü Etkisi}
ÖZET
Yapılan bu çalışmada, yerli diyatom toprağı Turco004'ün Patates Güvesi [Phthorimaea operculella (Zeller) (Lepidoptera: Gelechiidae)] pupasına karşı insektisidal etkisi laboratuvar şartlarında araştırılmıştır. Denemelerde diyatom toprağının toz halindeki formülasyonu uygulanmış ve dört farklı konsantrasyonu kullanılmıştır $\left(2.5,5,10\right.$ ve $\left.20 g^{-m^{2}}\right)$. Uygulamadan $24,48,72,96,120$, 144 ve 168 saat sonra pupa ağırlıkları ve ergin çıkışları kaydedilmiştir. Çalışma sonunda pupa ağırlıklarının zamana bağlı olarak önemli ölçüde etkilendiği görülmüştür. Ayrıca tüm dozlarda pupa açılımı engellenmiş ve herhangi bir ergin çıkışı gözlemlenmemiştir. Elde edilen veriler yerli diyatom toprağ Turco004' ün $P$. operculella'nın kontrolünde bir potansiyele sahip olabileceğini ortaya koymuştur.

$\begin{array}{ll}\text { Article History } \\ \text { Received } & : 10.04 .2020 \\ \text { Accepted } & : 30.06 .2020\end{array}$

Keywords

Native diatomaceous earth

Effect

Phthorimaea operculella

Pupae

\section{Research Article}

To Cite: Atay T, Alkan M, Ertürk S 2021. Insecticidal Efficacy of Native Diatomaceous Earth against Potato Tuber Moth, [Phthorimaea operculella (Zeller) (Lepidoptera: Gelechiidae)], Pupae. KSU J. Agric Nat 24 (1): 165-170. https://doi.org/ 10.18016/ksutarimdoga.vi.718094.

\section{INTRODUCTION}

The Potato tuber moth (PTM) (Phthorimaea operculella Zeller, (Lepidoptera: Gelechiidae) is an important pest that is harmful on the plants belonging to family Solanaceae including potato (Solanum tuberosum L.), tobacco (Nicotiana tabacum, L.), tomatoes (Solanum lycopersicum L.), pepper (Capsicum annuum L.), and eggplant (Solanum melongena L.) (Das and Raman, 1994; Rondon, 2010; Kroschel and Schaub 2012, Navrozidis and Andreadis 2012). This pest is one of the most important problem to potato production in the world. Cold winters restrict the development of the pest and reduce its harm. However, global warming may change PTM population dynamics and geographic distribution in the future. This pest has become invasive and is today reported more than 90 countries (Kroschel and Sporleder, 2006; Sporleder et al. 2007). This insect is spread to all potato growing areas or regions of Turkey.

PTM causes damage in both field and storage. Female lay eggs on the underneath of the plant leaves, flower, bud, leaves, and shoots. The eggs are left near the tuber eyes, near the surface or cracks of the soil, or on the potatoes stacked in the soil. In the field, larvae feed 
by mining in the leaves and shoots, and tunnelling in potato tubers. The damage due to potato moth larvae is seen principally during the storage period. $P$. operculella continues to give generation and previously infested tubers infect uninfected potatoes in the silo. Besides, damaged tubers are become more sensitive to be infected by bacteria and fungi (Golizadeh et al. 2014, Anonim 2020).

Stored crop losses in potatoes ranging from 50\% in Yemen and Peru, 86\% in Tunisia, Algeria, and Turkey, $90 \%$ in Kenya, and $100 \%$ in India and the Philippines have been reported (Alvarez et al. 2005). Çalışkaner et al. (1989) found that the damage of potato moth in storage period between $0.2-22 \%$ and density varies between one to 10, Bolu province in Turkey.

Synthetic chemicals are widely used for the control of potato tuber moths. However, environmental and human health problems caused by improper pesticides use, their side effects to beneficial organisms that are not targeted, the cost of insecticides used against PTM and residue problems. Researchers are trying to develop alternative methods for control of this insect due to the factors such as increasing demand for organic products, These alternative control methods include biological control, bio-pesticides, biotechnical and physical control. As an example of these studies, Shelke et al. (1985) have demonstrated that neem oil (Azadirachta indica, A. juss) has an anti-ovulation effect on PTM. Similarly, ethanol extract from Origanum majorana L. has a toxic effect on its larvae (Yeşilayer and Deniz 2019). Steven et al. (2008) stated that granulovirus (PoGV) and Bacillus thuringiensis Berliner ssp. kurstaki (Btk) can be used against larvae of potato tuber moth in field and storage conditions.

Diatomaceous earth (DE), which can be used within the scope of physical control methods, are fossilized silica residues of single cell microscopic algae known as diatoms. There are many studies on the toxicity of DE against insects of different pest groups (Ertürk et al. 2017). Athanassiou et al. (2004, 2005); reported that Silicosec $^{\circledR}$, PyriSec ${ }^{\circledR}$, and Insecto ${ }^{\circledR}$ DE were given complete mortality for Sitophilus oryzae (L.) (Coleoptera: Curculionidae) at doses of $1000 \mathrm{ppm}$ and above at $26{ }^{\circ} \mathrm{C}$ and $60 \%$ r.h. condition. Doğanay (2013) reported that the effectiveness of commercial diatom soil formulations Insecto ${ }^{\circledR}$ and native DE formulation Turco1 and Turco2 against $S$. granarius and Rhyzopertha dominica (Fabricius, 1792) (Coleoptera: Bostrichidae) wheat, rice and corn were given $100.0 \%$ mortality at high concentrations (750 and $1000 \mathrm{ppm}$ ). Atay et al. (2018) stated that PTM larvae are very susceptible to Turco004 showing an effect of approximately $100 \%$ after 24 hours of the DE exposure. However, there is no study on the toxicity effect of DE on PTM pupae. This study was conducted to determine the activity of diatomaceous earth against the PTM pupae in laboratory conditions.

\section{MATERIAL and METHODS}

\section{Phthorimaea operculella culture}

The preliminary culture of $P$. operculella was supplied from available infected potatoes in the Entomology Laboratory, Department of Plant Protection, Faculty of Agriculture, Tokat Gaziosmanpasa University, Tokat, Turkey. Immature stages of $P$. operculella were reared on potato tubers in a cage at $25 \pm 1^{\circ} \mathrm{C}, 65 \pm 5 \%$ r.h., and a photoperiod of 14:10 L:D. The cages were cylindrical (20 cm in diameter, and $50 \mathrm{~cm}$ in height) and covered by blotter paper and fine mesh gauze. The adults in the stock culture were fed with honey rubbed into the edge of the cage (Golizadeh et al. 2014).

\section{Diatomaceous earth}

Native diatomaceous earth Turco004 were acquired from a local commercial company from Ankara-Kazan and Beypazarı (Beg-tuğ Mineral). The particle sizes of the diatomaceous earth were 10-30 $\mu \mathrm{m}$ and mainly composes of $\mathrm{SiO}_{2}(83.26 \%)$ and other minerals $\mathrm{CaO}$ (3.49\%), $\quad \mathrm{Al}_{2} \mathrm{O}_{3}(6.25 \%), \quad \mathrm{Fe}_{2} \mathrm{O}_{3}(4.91 \%)$. Scanning electron microscope (SEM) image of Turco004 is presented in Figure 1.

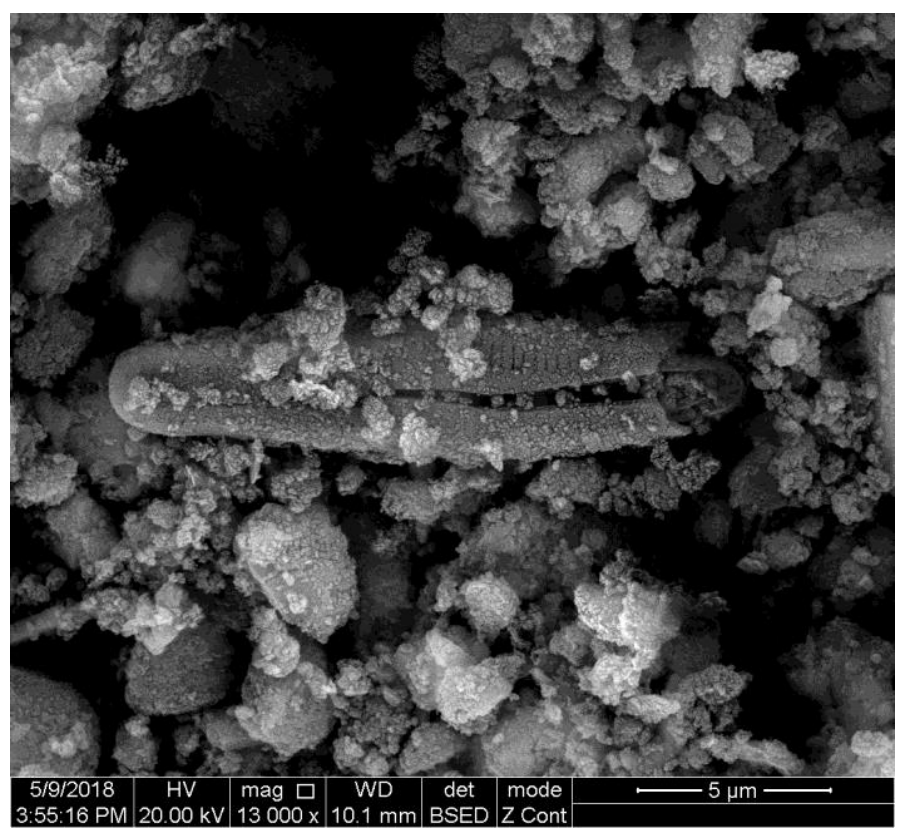

Figure 1. Scanning Electron Microscope image of Turco 004 showing general size and shape

Şekil 1. Turco 004'ün hacim ve şeklini gösteren Taramalı Elektron Mikroskop görüntüsü

\section{Bioassay tests}

The insecticidal activity of native DE Turco004 was tested against pupae of the PTM (two days old pupae). The bioassays were conducted at $25 \pm 1^{\circ} \mathrm{C}$ and $60 \pm 5 \%$ humidity with four concentrations of Turco004 (2.5, 5, 10 and $20 \mathrm{~g}^{-\mathrm{m}^{2}}$ ) in plastic cups with $3.5 \mathrm{~cm}$ diameter. For this purpose, DE was laid on the bottom of plastic cups with a camel hairbrush (No. 2) and pupae were 
placed on it (5 pupae per cup). The experiment was set in randomized blog design with 4 replications and the experiment was repeated 2 times. Pupae weights and the number of adults emerging from the pupae were recorded after 24, 48, 72, 96, 120, 144 and 168 hours of $\mathrm{DE}$ exposure. In the experiment, the control group were not treated with the DE.

\section{Statistical analysis}

Emerge Inhibition rate of PTM pupae was calculated using the below formula (Gökçe et al. 2012) that was modified from Abdelgaleil and Al-Aswad (2005). The calculated growth rates were subjected KruskalWallis test.

$E I=\frac{C W C-T W C}{C W C}$

Where EI: Emergence Index

CWC: Change in weight in the control (Initial weightpost treatment weight)

TWC: Change in weight in the treatment (Initial weight-post treatment weight)

The data for percent pupal emergency were subjected to arcsine transformation. Data were subjected to analysis of variance and differences among the treatments were compared by Tukey Multiple Comparison Test $(\alpha=0.05)$. Statistical analysis for data on growth rate and adult emergency rate were done using MINITAB ${ }^{\circledR}$ version 18 software package (McKenzei and Goldman 2005).

\section{RESULTS and DISCUSSION}

In the study, the effects of different concentrations of $\mathrm{DE}$ on the development of potato tuber moth pupae were evaluated. It was found that the weights of the pupae are significantly affected by the exposure time, while their weights were not significantly affected increasing by the DE concentrations (Figure 2). While DE treatment at the $2.5 \mathrm{~g}^{-\mathrm{m}^{2}}$ dose of the diatomaceous earth had an index value of 0.90 after at the end of 24 hours of $\mathrm{DE}$ exposure $(\mathrm{H}=1.02 ; \mathrm{df}=3)$, it had an index value of -0.50 after 168 hours of $\mathrm{DE}$ exposure $(\mathrm{H}=0.43$; $\mathrm{df}=3)$. In all other application concentrations $\left(5 \mathrm{~g}^{-\mathrm{m}^{2}}, 10\right.$ $\left.g^{-m^{2}}, 20 g^{-m^{2}}\right)$, these index values varied between 0.90 and -0.40 (Figure 2).

For adult emergence rates, the diatomaceous earth significantly prevented the pupal eclosion (Figure 3). No adult emergence from the pupae was observed at all DE concentrations applied. In the control group, adult emergence from the pupae was not seen after 24 hours, however, adult emergence was found after 48 hours. $(\mathrm{F}=1.75 ; \mathrm{df}=2,33 ; \mathrm{P}>0.05)$. Adult emergence started to increase after 72 hours and in this time zone, a $26.1 \%$ adult emergence rate was determined in the control group $(\mathrm{F}=12.6 ; \mathrm{df}=2.33 ; \mathrm{P}<0.05)$. Adult emergence rate in control group was $42.5 \%$ after 96 hours $(\mathrm{F}=88.5 ; \mathrm{df}=2,33 ; \mathrm{P}<0.05), 52.4 \%$ after 120 hours $(\mathrm{F}=198.1 ; \mathrm{df}=2.33 ; \mathrm{P}<0.05), 55.9 \%$ after 144 hours $(\mathrm{F}=344.1 ; \mathrm{df}=2,33 ; \mathrm{P}<0.05)$ and $65.1 \%$ after 168 hours $(\mathrm{F}=145.7 ; \mathrm{df}=2.33 ; \mathrm{P}<0.05)$ (Figure 3$)$.

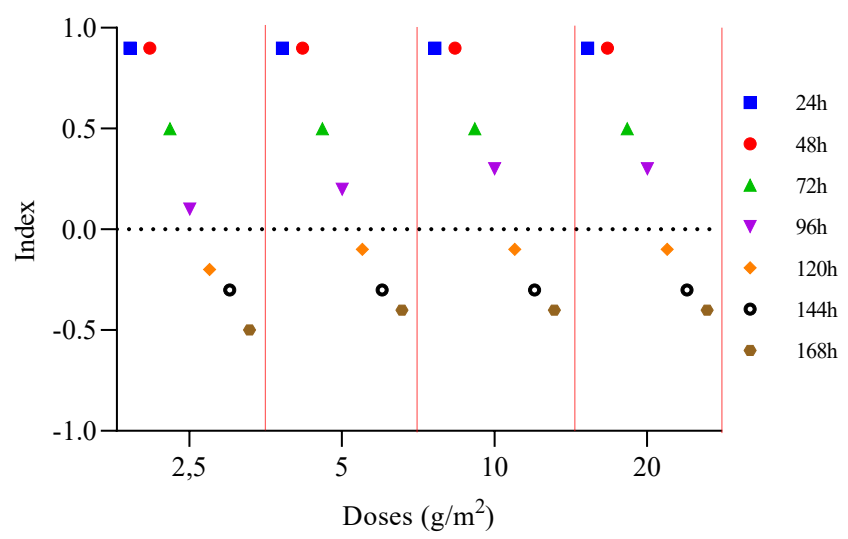

Figure 2. Weight losses caused by different doses of diatomaceous earth on potato tuber moth pupae

Şekil 2 Diyatom toprağının farklı dozlarının patates güvesi pupalarında meydana getirdiği ăğ

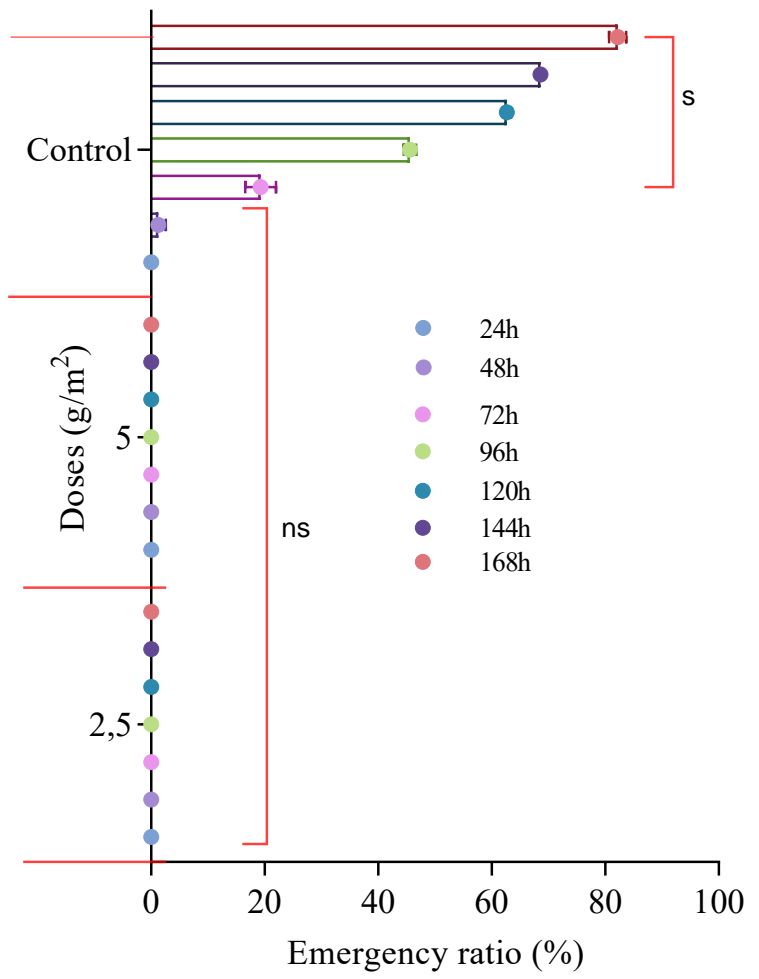

Figure 3. Effect of different doses of diatomaceous earth on emergence rates of adults of potato tuber moth

Şekil 3. Diyatom toprağının farklı dozlarının patates güvesi erginlerinin çıkış oranları üzerine etkisi

Previous studies showed that commercially available DE formulations are successfully used for controlling of stored product pests (Subramanyam et al. 1994, Ziaee 2007, Alkan et al. 2019, Bayram et al. 2019). In 
addition, these studies were mostly conducted on adult of Coleopteran insect species (Athanassiou et al. 2003, 2004, 2005). Diatomaceous earth is one of the most promising methods for controlling of stored-grain insects, which can be an alternative to conventional insecticides and fumigants (Korunic et al. 1996). Collantes et al. (1986), demonstrated that synthetic pyrethroid (deltamethrin, permethrin, cyfluthrin, flucythrinate, fenvalerate) insecticides were ineffective against PTM in field conditions. El-Kady (2011) found that $P$. operculella developed resistance against fenitrothion (500 $\left.\mathrm{g}^{-1} \mathrm{EC}\right)$, pirimiphos-methyl (250-1-EC), carbosulfan (10G $10 \% \mathrm{w} / \mathrm{w})$, aldicarb (10G $10 \% \mathrm{w} / \mathrm{w})$, lambda-cyhalothrin (50 $\left.\mathrm{g}^{-1} \mathrm{EC}\right)$, deltamethrin (25 $\mathrm{g}^{-1-}$ EC) and, imidaclopride (200 $\left.\mathrm{g}^{-\mathrm{l}} \mathrm{SL}\right)$ at varying rates.

Most insects make their breathing through spiracles that are part of the trachea system and open out of the body. It is known that insect's inhalation stops when these openings are closed by dust particles (Adedire et al. 2011, Ileke and Olotuah 2012). Sharaby et al. (2014) applied some essential oil compounds to the stored potato tubers using talcum powder. They concluded that these components prevent the insect to lay eggs and to enter the tubers. It is known that the diatomaceous earth causes death by damaging the insect integument (Ebeling 1971, Quarles 1992). As the diatomaceous earth mode of action does not depend on metabolic reactions, as in synthetic insecticides, more of the responses of inactive/immobil stages of insects to diatomaceous earth need to be studied. Mewis and Reichmuth (1999) applied the DE formulation Fossil Shield ${ }^{\circledR}$ against the Mealworms, Tenebrio molitor L. (Coleoptera: Tenebrionidae) pupa, revealing loss of weight in the pupa. Similarly, the data obtained from this study revealed that the DE used had a significant effect on the pupal eclosion of the potato moth and the weight of the pupae.

\section{CONCLUSIONS}

Diatomaceous earths form a physical barrier on insects, break down the epicuticular layers, cause fat absorption and therefore water loss, and also prevent the oxygen intake required for cell energy, causing death and weight loss in insects. This study reveals that diatomaceous earths significantly affected weights of the pupae and the number of adults emerging from the pupae. Despite this, exact mechanism of action of $\mathrm{DE}$ on the pupa yet is not known. For this reason, this study suggests that detailed and further physiological and biochemical studies are needed. The present study showed that, diatomaceous earth has a high potential as a natural preservative against pupae of $P$. operculella and could be suggested for integrated pest management programs (empty storage and tuber applications); however, further studies should be conducted under laboratory and storage conditions.
Declaration of competing interest

All authors declare that there are none interest to declare.

\section{Author's Contributions}

The contribution of the authors are equal.

\section{REFERENCES}

Abdelgaleil SAM, El-Aswad AF, 2005. Antifeedant and Growth Inhibitory Effects of Tetranortriterpenoids isolated from Three Meliaceous Species on the Cotton Leafworm, Spodoptera littoralis (Boisd.). Journal of Applied Sciences Research, 1(2): 234241.

Adedire CO, Obembe OM, Akinkurolere RO, Oduleye SO 2011. Response Callosobruchus maculatus Fabricius (Coleoptera: Chrysomelidae: Bruchinae) to Extracts of Cashew Kernels. Journal of Plant Diseases Protection 118 (2): 75-79.

Alkan M, Atay T, Ertürk S, Kepenekci, İ. 2019. Comparison of Bioactivities of Native Diatomaceous Earth against Turkestan Cockroach [Blatta lateralis Walker (Blattodea: Blattidae)] nymphs. Applied Ecology and Environmental Research, 17(3): 5987-5994.

Alvarez JM, Dotseth E, Nolte P. 2005. Potato Tuberworm a Threat for Idaho Potatoes. University of Idaho Extension, Idaho Agricultural Experiment Station, Moscow, ID.

Anonim, 2020. Patates Entegre Mücadele Teknik Talimati. Ankara.

Atay T, Ertürk S, Kumlu B, Alkan M, Duman A. 2018. Pre-Studies on Insecticidal Effect of Native Diatomaceous Earth against Potato Tuber Moth, [Phthorimaea operculella (Zeller) (Lepidoptera: Gelechiidae)], Larvae. I. International Agricultural Science Congress, 09-12 May, Van, Turkey.

Athanassiou CG, Kavallieratos NG, Tsaganou FC, Vayias BJ, Dimizas CB, Buchelos CThi 2003. Effect of Grain Type on the Insecticidal Efficacy of SilicoSec against Sitophilus oryzae (L.) (Coleoptera: Curculionidae). Crop Protection, 22 (10): 11411147.

Athanassiou CG, Kavallieratos NG, Andris NS 2004. Insecticidal Effect of Three Diatomaceous Earth Formulations against Adults of Sitophilus oryzae (Coleoptera: Curculionidae) and Tribolium confusum (Coleoptera: Tenebrionidae) on Oat, Rye and Triticale. Journal of Economic Entomology, 97 (6): 2160-2167.

Athanassiou CG, Vayias BJ, Dimizas CB, Kavalieratos NG, Papagregoriou AS, Buchelos C Th 2005. Insecticidal Efficacy of Diatomaceous Earth against Sitophilus oryzae (L.) (Coleoptera: Curculionidae) and Tribolium confusum Du Val (Coleoptera: Tenebrionidae) on Stored Wheat: Influence of Dose Rate, Temperature and Exposure Interval. Journal 
of Stored Products Research, 41(1): 47-55.

Bayram A, Işikber AA, Sağlam Ö, Şen R. 2019. Evaluation of Repellency Effect of Diatomaceous Earth Formulation (Detech ${ }^{\circledR}$ ) on Three Coleopteran Stored Grain Insects, 12 ${ }^{\text {th }}$ Conference of the Working Group Integrated Protection of Stored Product, 03-06 September, Pisa, Italy.

Collantes LG, Raman KV, Cisneros FH 1986. Effect of Six Synthetic Pyrethroids on Two Populations of Potato Tuber Moth, Phthorimaea operculella (Zeller) (Lepidoptera: Gelechiidae), in Peru. Crop Protection, 5(5): 355-357.

Çalışkaner S, Dortbudak N, Has A. 1989. Survey Studies on the Potato Tuber Moth (Phthorimaea operculella (Zeller)) in Central Anatolia. Plant Protection Bulletin, 29 (1-2): 65-74.

Das GP, Raman KV 1994. Alternate Hosts of the Potato Tuber Moth, Phthorimaea operculella (Zeller). Crop Protection. 13 (2): 83-86.

Ebeling W 1971. Sorptive Dusts for Pest Control. Annual Review of Entomology, 16: 123-158.

El-Kady H 2011. Insecticide Resistance in Potato Tuber Moth Phthorimaea operculella Zeller in Egypt. Journal of American Science, 7(10): 263-266.

Ertürk S, Ferizli AG, Emekci M 2017. Evaluation of Diatomaceous Earth Formulations for the Control of Rice Weevil, Sitophilus oryzae L., 1763 (Coleoptera: Curculionidae) in Stored Rice. Turkish Journal of Entomology, 41(3): 347-354.

Gökçe A, Isaacs, R, Whalon ME 2012. Dose-response Relationships for the Antifeedant Effects of Humulus lupulus Extracts against Larvae and Adults of the Colorado Potato Beetle. Pest Management Science, 68 (3): 476-481.

Golizadeh A, Esmaeili N, Razmjou J, Rafiee-Dastjerdi H 2014. Comparative Life Tables of the Potato Tuberworm, Phthorimaea operculella, on Leaves and Tubers of Different Potato Cultivars. Journal of Insect Science 14 (42): 1-11.

Ileke KD, Olotuah OF 2012. Bioactivity of Anacardium occidentals and Allium sativum Powders and Oils Extracts against Cowpea Bruchid, Callosobruchus maculatus (Fab) (Coleoptera: Bruchidae). International Journal of Biological Science 4 (1): 96103.

Korunic Z, Fields PG, Kovacs MIP, Noll JS, Lukow OM, Demianyk CJ, Shibley KJ 1996. The Effect of Diatomaceous Earth on Grain Quality. Postharvest Biology and Technology, 9 (3): 373-387.

Kroschel J, Sporleder M 2006. Ecological Approaches to Integrated Pest Management of Potato Tuber Moth Phthorimaea operculella Zeller (Lepidoptera, Gelechidae). Proceedings of the 45th Annual Washington State Potato Conference, Moses Lake, 7-9 February, Moses Lake, WA, USA.

Kroschel J, Schaub B 2012. Biology and Ecology of Potato Tuber Moths as Major Pests of Potato. (Insect Pests of Potato: Biology and Management,
Elsevier, Oxford: Ed. Giordanengo P, Vincent C, Alyokhin A) 165-192.

McKenzei JD, Goldman R 2005. The Student Guide to MINITAB Release 14 Manual. Pearson Education, Boston, MA.

Mewis I, Reichmuth C 1999. Diatomaceous Earths against the Coleoptera Granary Weevil Sitophilus granarius (Curculionidae) the Confused Flour Beetle Tribolium confusum (Tenebrionidae), the Mealworm Tenebrio molitor (Tenebrionidae). In: Proceedings of the 7th International Working Conference on Stored-product Protection 1998, 1. Sichnan Publishing House, Beijing, China, pp. 765780.

Navrozidis EI, Andreadis SS 2012. Applied Agricultural Entomology. CopyCity Publish, Thessaloniki, $538 \mathrm{pp}$.

Quarles W 1992. Diatomaceous Earth for Pest Control. IPM Practitioner ,14(1/6): 1-11.

Rondon SI 2010. The Potato Tuberworm: A Literature Review of Its Biology, Ecology, and Control. American Journal of Potato Research, 87 (2): 149166.

Sharaby A, Abdel Rahman H, Abdel-Aziz SH, Moawad SS 2014. Natural Plant Oils and Terpenes as Protector for the Potato Tubers against Phthorimaea operculella Infestation by Different Application Methods. Egyptian Journal of Biological Pest Control, 24 (1): 265-274.

Shelke SS, Jadhav LD, Salunkhe GN, 1985. Ovipositional and Adult Repellent Action of Some Vegetable Oils/Extracts against Potato Tuber Moth. Journal of Maharashtra Agricultural Universities, 10 (3): 284-6.

Sporleder, M, Kroschel J, Simon R 2007. Potential Changes in the Distribution of the Potato Tuber Moth, Phthorimaea operculella Zeller, in Response to Climate Change by Using a Temperature-driven Phenology Model Linked with Geographic Information Systems (GIS). XVI International Plant Protection Congress, CGIAR/SP-IPM Symposium "Emerging Themes in Agroecosystems Health and Food Safety", 15-18 October, Glasgow, Scotland UK.

Steven PA, Lawrence AL, Jonathan NP, Silvia IR 2008. Semi-field Evaluation of a Granulovirus and Bacillus thuringiensis ssp. kurstaki for Season-long Control of the Potato Tuber Moth, Phthorimaea operculella. Entomologia Experimentalis et Applicata, 129 (3): 276-285.

Subramanyam B, Swanson C L, Madamanchi N, Norwood S. 1994. Effectiveness of Insecto, a New Diatomaceous Earth Formulation in Suppressing Several Stored Grain Insect Species. In Proceedings of the 6th International Working Conference on Stored Product Protection, 17-23 April, Canberra, Australia. 
Yeşilayer A, Deniz M 2019. Toxic Effect of Four Different Plant Extracts on Potato Tuber Moth [(Phthorimaea operculella (Zeller) (Lepidoptera: Gelechiidae)] Eggs and Larvae. Turkish Journal of Agriculture-Food Science and Technology, 7 (12): 2239-2244.
Ziaee M, Safaralizadeh MH, Shayesteh N. 2007. Efficacy of Silicosec, a Diatomaceous Earth Formulation against Tribolium castaneum (Herbst) (Coleoptera: Tenebrionidae). Pakistan Journal of Biological Sciences, 10: 3841-3846. 